Studia Slavica 2010. Vol. 55. 307-318.

\title{
Optional word-order shifts in translation into and from Hungarian
}

\author{
KINGA KLAUDY \\ ELTE Fordító- és Tolmácsképző Tanszék, Budapest, Múzeum krt. 4/F, H-1088 \\ E-mail: kklaudy@ludens.elte.hu
}

\begin{abstract}
Word-order shifts take place in the course of the translation of almost every sentence of translated texts, regardless of language-pair and direction of translation. Some of these shifts are obligatory, since without them we would not get a grammatically correct TL sentence. Another class of word order shifts is not obligatory but optional. Optional word-order shifts are performed in order to ensure the cohesion of the TL text. Obligatory word-order shifts which lead to a grammatically correct TL sentence may distort the communicative structure: cohesive ties get loose, unimportant elements get highlighted and important elements are blurred. Many optional word-order changes are performed in order to preserve the communicative structure of the sentences, and thus the cohesion of the text. The present paper will discuss the different types of optional word-order shifts in translation from Hungarian to IE languages and vice versa.
\end{abstract}

Keywords: optional word-order shifts, fronting time and place adverbials, fronting the subject, shift of interruptions, shift of reporting clauses

\section{Introduction}

By shifts Catford (1965) means "departure from formal correspondence in the process of going from SL to TL" (1965: 73). Word-order shifts take place in the course of the translation of almost every sentence of translated texts, regardless of language-pair and direction of translation. Word-order shifts in translation of different language-pairs and registers are widely investigated in translation studies literature (Vinay and Darbelnet 1958/1965, Catford 1965, Nida 1969, Barkhudarov 1975, Newmark 1991, Munday 2001, Doherty 2003, Rogers 2006 etc.).

Some of these shifts are obligatory, since without them we would not get a grammatically correct TL sentence. Obligatory word-order shifts can be explained by the systemic differences between languages. Despite their obligatory character they are worth investigating, since it is only a departure from the SL is obligatory, while the TL often offers a range of options for the translator.

Another class of word-order shifts is not obligatory but optional. Even if they are not performed, translators can still obtain grammatically correct target language sentences. Optional word-order shifts are performed in order to ensure the cohesion of the TL text. Every language has different mechanisms to refer back to the previous sentence or to the entirety of the foregoing text. They also have various mechanisms to refer forward to the following sentence or to the entire subsequent text, and different ways to emphasise what they wish to say. Among these cohesive devices, the order of words plays an important role.

This article will investigate word-order shifts taking place in translation from Hungarian to four Indo-European (IE) languages: English, German, French and Russian and vice versa that is from IE languages to Hungarian. The corpus consist of approximately 50 English, 50 French, 50 German, and 50 Russian literary works and their Hungarian translations, and about 100 Hungarian literary works and their 25 English, 25 French, 25 German, and 25 Russian translations, that is, altogether about 300 book-length original work and their translations that is 600 literary works have been examined. Systematic analysis of this material 
was published in Klaudy (2003). Literary works were selected to avoid the database becoming quickly outdated. The masterpieces of Hungarian and world literature are only used as sources of language examples, and we do not intend to make relevant assumptions from the point of view of literary translation theory.

There are two major differences between IE languages and Hungarian, which explain the necessity of most word-order shifts. (1) One of these concerns the basic word-order of the sentence, i.e. the relative position of the arguments to the predicate. The basic word-order in IE languages under investigation is the SVO (subject-verb-object) type, while Hungarian is dominated by the SOV (subject-object-verb) type. (2) The other major difference is in the position of the modifiers within the noun phrase. While in IE languages noun phrases can be modified in two directions - postpositively and prepositively - in Hungarian the possibility of postpositive modification is severely limited, and all modifiers are placed in front of the head noun. Most obligatory word-order changes in IE-H and H-IE translation can be accounted for by these two systemic differences. On obligatory word-order shifts see more details in Klaudy 2003, this article will focus on optional word-order shifts in translation from Hungarian to IE languages and vice versa.

\section{Optional word-order shifts in translation}

\subsection{Contextual variants}

The flexibility of Hungarian word order does not imply a lack of sensitivity. The different word-order variants represent different contextual variants. The choice between them may influence the cohesion of the translated text.

Here we must broach the topic of optional word-order shifts. Optional word-order shifts are made by translators in order to strengthen the cohesive ties of the TL text. In translating from IE languages to Hungarian translators can choose among several options with respect to word order. The English sentence below has a number of grammatically correct Hungarian translations, each with a different word order. Taken out of context, all of the following translations may be equivalent to the English sentence.

(1) English ST: I found him looking for the dog between the palms of the garden.

(1a) Hungarian TT: (possible versions)

Amikor összetalálkoztunk, ('When we met')

...a kutyát kereste a kert pálmái között.

(lit: the dog he looked for between the palms of the garden)

...a kutyát a kert pálmái között kereste.

(lit: the dog between the palms of the garden he looked for)

...kereste a kert pálmái között a kutyát.

(lit: he looked for between the palms of the garden the dog)

...kereste a kutyát a kert pálmái között.

(lit: he looked for the dog between the palms of the garden)

...a kert pálmái közöt kereste a kutyát.

(lit:between the palms of the garden he looked for the dog)

...a kert pálmái között a kutyát kereste.

(lit: between the palms of the garden the dog he looked for)

If, however, we look at the preceding sentence in the context (Three days later his dog disappeared), it becomes evident that from among the above six options it is the first that is linked most closely to the previous sentence. 
(2) English ST: Three days later his $\boldsymbol{d o g}$ disappeared. I found him looking for it between the palms of the garden. (Greene 429)

(2a) Hungarian TT: Három nappal később eltünt a kutyája. Amikor összetalálkoztunk, a kutyát kereste a kert pálmái között. (Prekop 17)

The choice of the appropriate word-order variant may be influenced not only by the previous sentence but also by the following sentence. Out of the context the English sentence below may also have a number of different grammatically correct translations to Hungarian:

(2b) English ST: They met among the ruins at the edge of the village.

Hungarian TT: (possible versions)

A falu szélén találkoztak a romok között.

(lit: At the edge of the village they met among the ruins)

A romok között találkoztak a falu szélén.

(lit: Among the ruins they met at the edge of the village)

A falu szélén a romok között találkoztak

(lit: At the edge of the village among the ruins they met)

A romok között a falu szélén találkoztak.

(lit: Among the ruins at the edge of the village they met)

If, however, we look at the next sentence (The ruins had always been there), it becomes evident that the first sentence must end with "ruins", since this provides a thread of continuity.

(2c) English ST: They met among the ruins at the edge of the village. The ruins had always been there. (Greene 300)

Hungarian TT: A falu végén találkoztak a romok között. A romok időtlen idő óta ott voltak. (Kéry 241)

\subsection{Fronting time and place adverbials}

There are two optional shifts which frequently occur at the beginning of sentences in both directions: fronting time or place adverbials and fronting the subject. Fronting an element of the sentence we move it into sentence initial position.

To begin the sentence with time or place adverbials is quite natural in all languages. They are very suitable for the topic role, therefore they are very often used for topicalisation. In the example below, topicalisation is optional because the Hungarian sentence could have begun right with the focus, but the translator decided to move the time adverbial into sentence initial position.

(3) English ST: There was a case of much the same kind in Northumberland a year ago. (Christie 18)

(3a) Hungarian TT: Tavaly nagyon hasonló dolog történt Northumberlandban. (Borbás 19) (lit: Last year a case of much the same kind happened in Northumberland)

Fronting time and place adverbials does not necessarily mean topicalisation. In the following examples time adverbials are in focus position in the English sentence (end-focus) and fronting them brings them into focus position in the Hungarian sentence, too (preverbal focus). 
(4a) Hungarian TT: Tegnap este beszéltem anyával telefonon. (Elbert 9)

(5) English ST: The first time she left her chamber was at the commencement of the following March. (E. Brontë 171)

(5a) Hungarian TT: Március elején jöhetett ki először szobájából. (Sőtér 130)

\subsection{Fronting the subject}

Fronting the subject is a frequent shift in both directions. In H-IE translation it is often obligatory because of the restrictions on word order in IE languages. In IE-H translation fronting the subject is always optional. Since the subject in Hungarian is identified morphologically and not positionally, it can stand anywhere in the sentence. Translators, nevertheless, often place the subject into sentence initial position in IE-H translation.

The type of sentence where the subject is first identified by a personal pronoun (preparatory subject) and is concretised only in the second half of the sentence is fairly common in IE languages. In such cases, the concrete subject may be brought forward in the translation. In the case of the French example from Flaubert's Madame Bovary, we have two published translations, both made by well-known professional translators. The optional nature of this shifts is illustrated by the difference between the two translations of (7): the subject is fronted only by the first translator (7a).

(6) English ST: Now that he realized there was nothing to be done about it... Number One made little trouble. (Greene 305)

(6a) Hungarian TT: Egyes, látva, hogy nincs mit tennie, most már nem sok vizet zavart. (Kéry 244)

(7) French ST: Comme il s'ennuyait beaucoup à Yonville, où $i l$ était clerc chez maître Guillaumin, souvent M. Léon Dupuis (c'était lui, le second habitué du "Lion d'or") reculait l'insistant de son repas ... (Flaubert 84)

(7a) First translation, fronting the subject:

Hungarian TT: Mivel Léon Dupuis, Guillaumin jegyző segédje (mert ő volt az Arany Oroszlán másik állandó vendége) igen unatkozott Yonville-ban, próbálta minél későbbre tolni az étkezés idejét ... (Gyergyai 101)

(7b) Second translation, not fronting the subject:

Hungarian TT: Nagyon unatkozott Yonville-ban Léon Dupuis úr (ő volt az Arany Oroszlán másik kosztosa), Guillaumin jegyző úr segédje, ezért igyekezett késleltetni a vacsorát, ... (Pór 89)

This shift is reversible: in translating form Hungarian to IE translators remove specific subjects from the beginning of the sentence and replace them by preparatory subjects (8).

(8) Hungarian ST: Zetelaki késett ugyan egy kicsit, s az első felvonásban feltűnően fáradtnak látszott (néhol szemlátomást a súgó segítségére szorult), de aztán egyre jobban magára talált, ... (Örkény 13)

(8a) English TT: Though a few moments late and looking rather the worst for wear during Act 1 (here and there he had to rely on the prompter) Zetelaky gradually revieved, ... (Sollosy 57)

Another characteristic IE sentence type begins with an introductory participial or 
nominal phrase and the subject comes later, in the main clause. Elevation of the IE participial or nominal phrase into an independent sentence unit in IE-H translation is frequently accompanied by fronting of the subject as it can be seen in (9) and (10).

(9) English ST: Without looking at his brother, Francis said...(Greene 558)

(9a) Hungarian TT: Francis nem is nézett a testvérére, amikor így szólt:...(Osztovits 316)

(10) French ST: Par un mouvement involontaire, et malgré la recommandation faite, D’Artagnan lance son cheval au galop (Dumas 394)

(10a) Hungarian TT: D' Artagnan az intelem ellenére önkéntelen vágtára sarkantyúzta a lovát ... (Csatlós 375) the subject.

In example (11) both translators of Madam Bovary applied the device of fronting of

(11) French ST: Sans qu'il s'en aperçut, tout en causant, Léon avait posé son pied sur un des barreaux de la chaise où madame Bovary était assise. (Flaubert 89)

(11a) First translation, fronting the subject:

Hungarian TT: Leon, miközben így beszélt, észre sem vette, hogy egyik lábát Bovaryné székének keresztrúdján nyugtatta. (Gyergyai 107)

(11b) Second translation, also fronting the subject:

Hungarian TT: Léon társalgás közben maga se vette észre, hogy ráteszi a lábát Bovaryné székének keresztlécére. (Pór 94)

As illustrated in (12) and (13) this shift is also reversible: when translating into the opposite direction, translators create introductory nominal and participial phrases removing the subject from sentence initial position.

(12) Hungarian ST: A Lear király esti elöadása e tragikus esemény ellenére is zavartalanul folyt le. (Örkény 13)

(12a) English TT: Despite this terrible misfortune, tonight's performance of King Lear proceeded as usual. (Sollosy 57)

(13) Hungarian ST: Zsolozsmai, ahelyett, hogy gyorsan odébbállt volna, félszegen kalapot emelt. (Örkény 1.209)

(13a) English ST: Instead of walking away, in his embarrassment Zsolozsmai shyly tipped his hat. (Sollosy 49)

Fronting the subject often takes place in IE to Hungarian translation without any visible reason (14). The optional nature of fronting is illustrated by the two equally adequate versions of the French example (15): the first (15a) without and the second (15b) with fronting.

(14) English ST: For the second time that morning, Mr. Boggis explained at some length the aims and ideals of the Society for the Preservation of Rare Furniture. (Dahl 140)

(14a) Hungarian TT: Mr. Boggis a nap folyamán immár másodszor magyarázta el részletesen a Régi Bútorok Megóvására Alakult Társaság célkitűzéseit és eszményeit. (Borbás 141) 
(15) French ST: De l'autre côté de la cheminée, un jeune homme à chevelure blonde la regardait silencieusement. (Flaubert 89)

(15a) First translation, without fronting the subject:

Hungarian TT: A tüzhely másik oldalán szőke hajú fiatalember állt és csendesen nézegette. (Gyergyai 101)

(15b) Second translation, fronting the subject:

Hungarian TT: Egy szőke fiatalember fiatalember nézte Emmát szótlanul a tüz másik oldaláról. (Pór 89)

The seemingly unjustified fronting of the subject in IE-H translation can be explained partly by the habitual character of this shifts. Translators do it so often that it becomes second nature with them, a language pair specific translation strategy. Another explanation can be that there exists a universal translation strategy that we may call fronting "sign-posting" elements. Translators try to do their best to make clear the structure of a sentence as soon as possible. Where a sentence begins with a subject, the reader will receive an important cue for comprehension from the very first word of the sentence.

\subsection{Defronting of sentence initial conjunctions}

By defronting we mean removing an element from sentence initial position. This happens with certain conjunctions in IE-H translation. Defronting of sentence initial conjunctions is an optional word-order shift, which cannot be explained by syntactic differences between languages. In IE-H translation some conjunctions and conjuncts, for instance the adversative ones: viszont ('on the other hand'), ellenben ('on the contrary'), the confronting ones: azonban ('but'), pedig ('however'), the inductive ones: tehát ('therefore') and the explanatory ones: ugyanis ('namely'), tudniillik ('namely') are removed from the beginning of the sentence and are placed after the first noun or nominal phrase of the Hungarian sentence (16a),(17a),(18a),(19a).

English $\rightarrow$ Hungarian:

(16) English ST: Perhaps his father was in the right about his age. (Greene 299)

(16a) Hungarian TT: Apa alighanem jobban tudja az ő korát. (Kéry 240)

French $\rightarrow$ Hungarian:

(17) French ST: Cependant, avant d'entrer dans le détail de ces nouveaux événements, le narrateur croit utile de ... (Camus 21)

(17a) Hungarian TT: Az elbeszélő azonban, mielőtt újabb események részleteibe hatolna ... (Györi 259)

German $\rightarrow$ Hungarian:

(18) German ST: Aber unter Tonio's runder Pelzmütze blickten aus einem brünetten und ganz südlich scharfgeschnittenen Gesicht dunkle und zart umschattete Augen mit zu schweren Lindern träumerisch und ein wenig zaghaft hervor ... (Mann 10)

(18a) Hungarian TT: Tonio kerek prémsüvege alól barnás és déliesen éles metszésü arcából ellenben sötét, szeliden árnyékolt, túlságosan súlyos pillájú szempár pillantott elö álmodozón és kissé félénken. (Lányi 11)

Russian $\rightarrow$ Hungarian: 
(19) Russian ST: Odnako istoriya znaet yeshcho bolee visokuyu tsenu. (Zoshchenko 258)

(19a) Hungarian TT: A történelem azonban még magasabb vérdíjat is feljegyzett. (Rab 37)

Removing certain types of the conjunctions from sentence initial position in IE-H translation is an optional word-order shift, which cannot be explained by grammatical differences between the languages. Nevertheless, it is a habitual transfer operation: professional translators do it regularly, and apparently it is a language pair specific translation strategy with them. Explanation might be given by the analysis of the functional perspective of the Hungarian sentence. We have already mentioned that because of the SOV word order in Hungarian, the borderline between the topic and comment can be blurred. If we analyse the above examples, we can see that conjunctions are placed after the topic part of the sentence, serving as special borderline markers between the topic and the comment.

This function becomes clear if we look at the Hungarian translation of the German example, in which the topic consists of long, extended nominal phrases and the verb is shifted towards the end of the sentence. In this Hungarian translation, the conjunction ellenben (cf: sentence initial Aber in German) is an important borderline marker between the topic and the comment, and helps the reader to better (and earlier) understand the sentence structure.

\subsection{Shift of interruptions}

By interruption we mean cases when certain elements (phrases or clauses) are inserted into the sentence, separating two elements, which would normally follow each other. The possibilities of interruption vary from language to language. In languages with a rich morphology and a free word order, sentences can be interrupted more easily than in languages with a poor morphology and fixed word order. Since sentences can only rarely be interrupted at the same point, translators are frequently compelled to change the position of the inserted structure, or eliminate the interruption.

In translating interrupted sentences, translators have to construct a new framework for interruption in the translated text. The framework divides the sentence into the part preceeding the interruption (left frame) and that following the interruption (right frame). The left frame must contain enough information to predict the ensuing structure of the sentence. In the example below, because of the degradation of the beginning of the sentence in IE-H translation, the left frame would be too short and therefore the translator removed the focus from the right frame in German and transposed it into the left frame in Hungarian.

(20) German ST: Er schritt - und niemand schritt wie er, elastisch, wogend, wiegend, königlich - auf die Herrin des Hauses zu, verbeugte sich und wartete, daß man ihm die Hand reiche. (Mann 40)

(20a) Hungarian TT: A ház úrnőjéhez lépett - és senki sem lépdelt olyan rugalmasan ingva-ringva, oly királyian -, meghajtotta magát, és várta, hogy a hölgy kezet nyújtson. (Lányi 41)

The following examples illustrate the elimination of interruption in IE-H translation. Because of the usual degradation of the sentence beginning in IE-H translation (obligatory omission of the personal pronoun, incorporation of the auxiliary verb into the main verb and the left-position of the non-verbal focus), there is nothing left in the translation, which could give a left framework for the insertion. Therefore the translator moved the inserted part into sentence initial position, and transformed it into a topic in the English-Hungarian translation (21a) and into an independent sentence unit in the French-Hungarian translation (22a). 
(21) English ST: He could even, with some difficulty, look back into the past. (Greene 299)

(21a) Hungarian TT: Némi megeröltetéssel még a múltba is vissza tudott tekinteni. (Kéry 240)

(22) French ST: Il s'était enveloppé, au sortir du bain, d'une ample serviette de tissu bouclé ... (Vian 9)

(22a) Hungarian TT: Amikor kijött a kádból, hatalmas bolyhos törülközőbe csavarta magát; (Bajomi 7)

\subsection{Shift of reporting clauses}

Changing the position of reporting clauses is another word-order shift, affecting the whole sentence structure. This is also a partly obligatory and partly optional transfer operation. The reporting clauses accompanying a quotation may be transposed freely around the quotation in all the languages under consideration. The reporting clauses may introduce, interrupt or close the quotation.

Short introductory reporting clauses (like he/she said, er/sie sagte, on/ona skazala) are often transposed into the middle or the end of the sentence in IE-H translation. The reason for this operation is very simple: omission of the personal pronoun would leave the introductory reporting clause incomplete:

(23) English ST: She said, 'It is lovely. Let's drive a long way.' (Greene 436)

(23a) Hungarian TT: - Nagyszerü. Menjünk el jó messzire - mondta a lány. (Prekop 263)

(24) German ST: Er sagte, wir wären verrückt, weil wir kein Geld hatten, wir sollten doch etwas verscheuern; (Böll 33)

(24a) Hungarian TT: - Eszünk sincs, ha pénzünk nincs, - mondta a tizedes ${ }_{2}$ - miért nem dobunk el valamit; (Bor 33)

Perhaps under the influence of analogy, Hungarian translators often remove reporting clauses from sentence initial position even in cases where there is no danger of incompleteness (25a). Again, this procedure can be seen as a specific translation strategy.

(25) English ST: The very first question she asked Snowball was: 'Will there still be sugar after the Rebellion?'(Orwell 10)

(25a) Hungarian TT: - Lesz-e cukor a forradalom után is - kérdezte legelöször is Hógolyótól.(Szíjgyártó 17)

If the reporting clause interrupts a quotation, the same principles apply as in the case of sentence interruption. Options for interrupting are heavily dependent on the syntactic possibilities of individual languages. If the left frame of the interruption is too short, or incomplete, translators eliminate the interruption and transpose the reporting clause to the end of the sentence.

(26) French ST: - Aussi, disait Rodolphe, je m'enfonce dans une tristesse... (Flaubert 152)

(26a) Hungarian TT: - Magam is egyre jobban belesüppedek a szomorúságba... mondta Rodolphe. (Pór 152) 
(27) French ST: - Je devrais, dit Rodolphe, me reculer un peu. (Flaubert 156)

(27a) Hungarian TT: - Hátrább kellett volna húzódnom -- szólalt meg Rodolphe. (Pór 156)

(28) French ST: -Alors, Jacques, dit sa mère, tu te portes bien? (Cocteau 52)

(28a) Hungarian TT: - Szóval jól vagy, Jacques? - szólt az édesanyja. (Pór 53)

In the following examples (29), (30) the interruption is eliminated and the reporting clauses interrupting the quotation in the original are transposed to the beginning of the sentence in the translation. The reason is the same: obligatory word-order changes eliminate the left frame (first example) or cut it too short (second example).

(29) German ST: "So einen Blick", erzählte er zwei Jahre später, "hab ich in meinem Leben noch nicht gesehen." (Seghers 146)

(29a) Hungarian TT: Két esztendővel később így beszélte el a dolgot: - Életemben nem láttam olyan tekintetet. (Thury 142)

(30) German ST: Man gerät, sagte ich unbeirrt, damit in die Rolle des Verneiners der Werke, man wird zum Anwalt des Nichts. (Mann 187)

(30a) Hungarian TT: Én azonban makacsul folytattam a magamét: Az ember ezáltal a müvek tagadójává, a Semmi prókátorává szegődik. (Szőllősy 229)

If the left frame is a complete clause, the interrupting reporting clause retains its place in the translation.

The end of the quotation is the most natural place for the reporting clause in all the languages under investigation. The optional character of the shift of reporting clauses is illustrated by the following examples (31), (32), where closing reporting clauses of the original are transformed into interrupting reporting clauses in the translation.

(31) English ST: 'If you were my boy I'd take you out and gamble', he said. (Hemingway 3)

(31a) Hungarian TT: - Ha az én fiam volnál - mondta -, vállalnám a kockázatot és magammal vinnélek. (Ottlik 7)

(32) English ST: 'The germs of influenza can only exist in an acid condition', he explained. (Hemingway 162)

(32a) Hungarian TT: - Az influenza kórokozói - magyaráżta a doktor - csak az acidosis állapotában tenyésznek. (Róna 163)

The explanation can be found in the topic-comment structure of the reporting clauses. In Hungarian the most typical reporting verb mondta is a weak verb which is open to the left and puts the emphasis on the first element standing on its left side. With transposing the reporting clause after the first clause or after the first noun phrase, the transposed reporting verb puts the emphasis on them.

\section{Summary remarks}

Word-order shifts on the clause/sentence level cannot be discussed without the consideration of the communicative structuring (topic-comment structure) of the sentence. Obligatory word-order shifts which lead to a grammatically correct TL sentence may distort 
the communicative structure: cohesive ties get loose, unimportant elements get highlighted and important elements are blurred. Many optional word-order changes are performed in order to preserve the communicative structure of the sentences, and thus the cohesion of the text.

Optional word-order shifts can be explained by the different means of the communicative structuring in Hungarian and IE languages: for example, mid-focus in Hungarian and end focus in IE, regressive focussing in Hungarian and progressive focusing in IE, blurred borderline between the topic and the comment in Hungarian and clear borderline in IE, etc.

Some optional word-order shifts cannot be explained by the requirements of communicative structuring. Hungarian translators, for instance, often move the subject to sentence initial position although the subject can stand anywhere in the sentence. They often transpose introductory reporting clauses to the end of the sentence, even though it is not always necessary, etc. These are habitual transfer operations which Hungarian translators perform regularly in translating from IE languages.

And finally, especially in translation into Hungarian where word order is free, there are a lot of word-order shifts, which can be explained only by the translator's individual preferences. This is similar to our inability to always explain the choices between synonyms in the case of lexical transfer operations. This is the translator's playground, the province of translational freedom. While translating, the translators do not only see the text, but hear it as well. For them the text has an "internal melody" and it is this internal melody they follow in choosing among the various word-order options.

\section{References}

Barkhudarov, L. S. 1975a. Yazik i perevod. Moscow: Mezhdunarodnie otnosheniya.

Catford, J. C. 1965. A Linguistic Theory of Translation. London: OUP.

Doherty, M. 2003. Parametricized Sentence Beginnings of Sentences in English and German. Across Languages and Cultures Vol. 4. No.1. 19-51.

Munday, J. 2001. Introducing Translation Studies. London: Rotledge.

Klaudy, K. 2003. Languages in Translation. Budapest: Scholastica.

Newmark, P. 1991. About Translation. Clevedon: Multilingual Matters.

Nida, E. A., Taber, Ch. R. 1969. The Theory and Practice of Translation. Leiden: Brill.

Rogers, M. 2006. Structuring Information in English: A Specialist Translation Perspective on Sentence Beginnings. The Translator Vol. 12. No. 1. 29-65.

Vinay, J.P., Darbelnet, J. 1958. Stylistique comparée du français et de l'anglais. méthode de traduction. London-Toronto-Paris: Didier.

Vinay, J.P., Darbelnet, J. 1995. Comparative Stylistics of French and English. A methodology for Translation. Amsterdam: Benjamins. Translated by Juan C. Sager and M.J. Hamel.

\section{Sources}

Böll, H. 1967. Wanderer, kommst du nach Spa... Erzälungen. München: Deutscher

Tascenbuch Verlag.

Böll, H. 1986. És lőn este reggel. Válogatott elbeszélések. Bp: Európa. Translated by Bor Ambrus, Raymann Katalin.

Bronte, E. 1988. Wuthering Heights. OUP.

Bronte, E. 1975. Üvöltő szelek. Bp: Európa. Translated by Sőtér István. 
Camus, A. 1947. La peste. Paris: Éditions Gallimard.

Camus, A. 1983. A pestis. Regények és elbeszélések. Bp: Európa. Translated by Győri János.

Christie, A. 1988. Philomel Cottage. Bp: Európa.

Christie, A. 1988. Fülemüle-villa. Bp: Európa. Translated by Borbás Mária.

Cocteau, J. 1923. Le grand écart. Paris: Éditions Stock

Cocteau, J. 1991. A nagy mutatvány. Bp: Európa. Translated by Pór Judit

Dahl, R. 1961. Parson's Pleasure. Short Stories. Bp: Európa.

Dahl, R. 1961. Jámbor örömök. Elbeszélések. Translated by Borbás Mária.

Dumas, A. 1995. Les Trois Mousquetaires. Série "Le livre Poche" Paris: Librairie Générale Française.

Dumas, A. 1969. A három testőr. Bp: Európa. Translated by Csatlós János.

Flaubert, G. 1930: Madame Bovary. Paris: Fasquelle Éditeurs.

Flaubert, G. 1984. Bovaryné. Bp: Európa. Translated by Gyergyai Albert.

Flaubert, G. 1993. Bovaryné. Bp: Európa. Translated by Pór Judit.

Greene, G. 1972. Collected Stories. London: The Bodley Head.

Greene, G. 1974. Az utolsó lehetőség. Válogatott elbeszélések. Bp: Európa. Translated by Borbás Mária, Halápy Lili, Kéry László, Osztovits Levente, Örkény István, Prekop Gabriella, Sükösd Mihály, Szobotka Tibor, Takács Ferenc, Török Gábor.

Hemingway, E. 1987. The End of Something. Selected stories. Bp: Európa.

Hemingway, E. 1987. Valami véget ér. Válogatott elbeszélések. Bp: Európa. Translated by Szász Imre, Róna Ilona, Réz Ádám, Ottlik Géza.

Mann, T. 1975. Tonio Kröger. Bp: Európa.

Mann, T. 1975. Tonio Kröger. Bp: Európa. Translated by Lányi Viktor.

Mann, T: 1977. Doktor Faustus. Das Leben des deutschen Tonsetzers Adrian Leverkühn, erzählt von einem Freunde. Franfurt am Main: Deutsche Taschenbuch Verlag.

Mann, T: 1977. Doktor Faustus. Adrian Leverkühn német zenszerző élete, elmondja egy barátja. Bp: Európa. Translated by Szöllösy Klára.

Orwell, G. 1950. Animal Farm. A Fairy Story. London: Secker and Warburg.

Orwell, G. 1989. Állatfarm. Bp: Európa. Translated by Szíjgyártó László.

Örkény István 1968. Egyperces novellák. Bp: Magvető.

Örkény István 1994. One Minute Stories. Sydney: Brandl and Schlesinger. Translated by Sollosy Judy.

Salinger, J.D. 1991. Franny a Zooey. London: Penguin Books.

Salinger, J.D. 1986. Franny és Zooey. Bp: Európa. Translated by Elbert János, Tandori Dezső.

Seghers, A. 1970. Das siebte Kreuz. Leipzig: Verlag Philip Reclam jun.

Seghers, A. 1979. A hetedik kereszt. Bp: Európa: Translated by Thury Zsuzsa.

Vian, B. 1963. L'écume des jours. Paris: Jean-Jacques Pauvert.

Vian, B. 1969. Tajtékos napok. Bp: Európa. Translated by Bajomi Lázár Endre.

Zoshchenko, M. 1990. Golubaya kniga. Kishinov: Kartya Moldovenyanskiye.

Zoscsenko, M. 1970. Kék könyv. Bp: Európa. Translated by Rab Zsuzsa. 